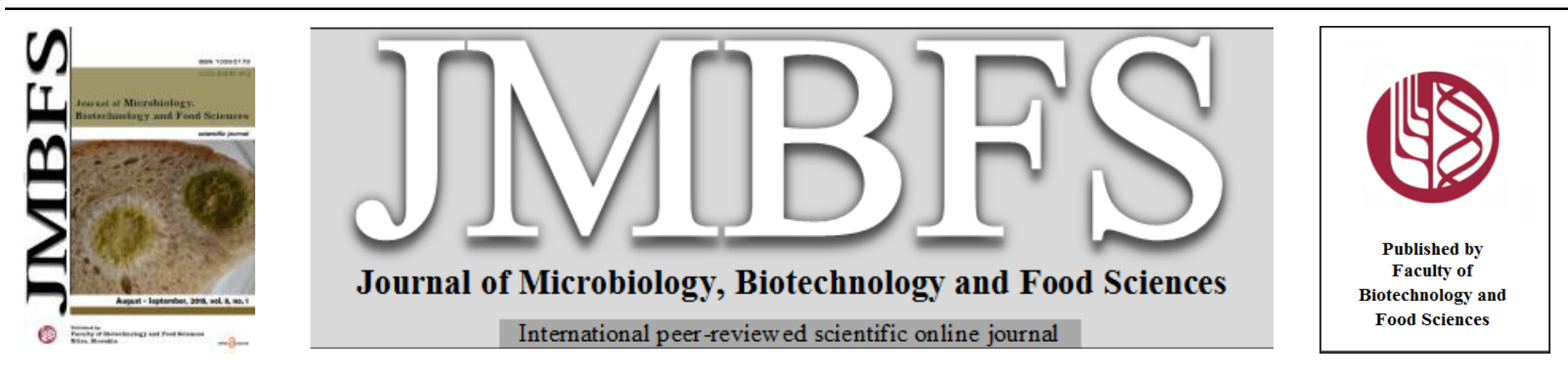

\title{
COMPARING THE PHYSICO-CHEMICAL CHARACTERISTICS AND SENSORY ATTRIBUTES OF IMPORTED BRAZILIAN BEEF MEAT AND IMPORTED INDIAN BUFFALO MEAT
}

\author{
Marwa A. Hassan, Heba H.S. Abdel-Naeem*, Hussein M.H. Mohamed, Nabil A. Yassien \\ Address(es): \\ Department of Food Hygiene and Control, Faculty of Veterinary Medicine, Cairo University beside Students Hospitals, Giza Square, Giza 12211, Egypt. \\ *Corresponding author: h.hussein@cu.edu.eg \\ doi: 10.15414/jmbfs.2018.8.1.672-677 \\ ARTICLE INFO \\ Received 23. 4. 2018 \\ Revised 17. 6. 2018 \\ Accepted 18. 6. 2018 \\ Published 1. 8. 2018 \\ Regular article \\ OPEN $\partial_{\text {ACCESS }}$

\begin{abstract}
The main objective of the current study was to compare the physico-chemical characteristics and sensory attributes of imported Brazilian beef meat and imported Indian buffalo meat. Chuck samples were collected and examined for proximate chemical composition, soluble proteins, $\mathrm{pH}$, TVB-N, TBA, color, shear force, fatty acid profile and sensory attributes. The results revealed higher total protein, fat, total soluble protein and lower collagen solubility of imported frozen Indian buffalo meat chuck samples. However, there is nonsignificant difference in $\mathrm{pH}, \mathrm{TVB}-\mathrm{N}, \mathrm{TBA}$, fatty acid profile. Sensory attributes indicated significantly higher appearance, tenderness and juiciness scores for imported Brazilian beef meat. Moreover, the significant decreasing shear force, $\mathrm{a}^{*}$ and significant increasing $\mathrm{L}^{*}$ values were observed in imported frozen Brazilian meat chuck samples. These attributes can make Indian buffalo meat a good choice for meat processing after Brazilian beef meat. Moreover, these results will help meat processors to find an alternative source for raw meat
\end{abstract} \\ materials for production of high quality meat products.
}

Keywords: Imported Brazilian meat, Imported Indian meat, technological properties, sensory

\section{INTRODUCTION}

Native breeds of cattle represent the main source of high quality meat for Egyptians due to their considerable contents of proteins, essential amino acids, vitamins and iron. However, the continuous increasing of the prices of these meat in recent years in Egypt, due to slow growth in domestic meat production, resulted in rapid increase in the demand for meat to satisfy the daily need of consumers. It has been reported that the demand of people for red meat was doubly increased as result of the crises of avian influenza which widely spread all over the world (Badawi, 2008).

Currently, Egypt is facing a great problem of how to provide adequate supplies of meat and how to overcome increasing the prices of local meat. With current low meat production, meat importation is the main option to bridge the gap between the consumption and domestic supply. Imported frozen meat is considered a great source of meat which have become accepted and consumed all over the Arabic World. Egypt is considered one of the main countries which depend mainly on importation of frozen meat (Abdelaziz et al., 2017).

Egypt imports great amounts of frozen meat every year from different countries not only to reflect their consumer's local needs but also importation of meat was formed as a main part of the process of greater harmonization of trade in our market (Al-Sabagh et al., 2016). Moreover, the meat processing industries require consistent supplies of high quality meat as basic ingredients and this demand cannot be met locally and they are totally reliant on imported meat. The amount of imported frozen beef in Egypt reaches about 138670 tons and buffalo meat is 88322 tons (GOVS, 2017).

The key suppliers of frozen meat in 2015 were Brazil, India, Sudan, United States and Australia. Brazil is the dominant supplier of the frozen beef while India is the sole supplier of frozen buffalo meat. It is estimated that $80 \%$ of the Brazilian herd consists of Zebu (Bos indicus) breeds (ABIEC, 2014; USDA, 2014; Aroeira et al. 2016). India is the largest buffalo meat producer (1.48 million MT) and exporter (0.343 million tons) in the world (FAO, 2004). In 2016, the frozen meat imports have totaled 301,244 MT (million ton), of which 101,044 MT or 33 percent are frozen buffalo meat from India, while 196,934 MT are frozen bovine meat mainly from Brazil.

In the recent years, there has been a tendency for consuming meat products among the Egyptian consumers due to continuous changes in the life style. Moreover, with the high cost of meat and the demand of a growing population, the technological developments in meat processing has given consumers a much greater choice over the food they can buy (Vernam and Sutherland, 1995).
Meat processing in Egypt depends mainly on the imported frozen meat to save local meat as a table meat. Therefore, it is important to choose the most suitable meat of high quality to enable meat industry to produce high quality meat products. To the best of our knowledge, the study of technological, nutritional and sensory characteristics of frozen meat obtained from different sources still limited. Therefore, the objective of the current research was to study the technological properties, nutritional quality and sensory characteristics of imported beef and buffalo. This study may help meat processors in different countries to choose the best meat to be imported and used as a raw material for processing of different meat products.

\section{MATERIAL AND METHODS}

\section{Preparation of meat samples}

Samples of imported frozen chucks of Brazilian beef and Indian buffalo within the first third of their shelf life were obtained from different meat stores in Cairo, Egypt. Each sample (Longissimus dorsi) was represented by 3 blocks ( $2 \mathrm{~kg}$ each). The samples were transferred immediately in cooling ice box to the laboratory of Food Hygiene Department, Faculty of Veterinary Medicine, Cairo University. In the laboratory the external fat and connective tissue of each block were dissected and each block was prepared for estimation of proximate chemical composition, soluble proteins, $\mathrm{pH}$, TVB-N, TBA, color, shear force, fatty acid profile and sensory attributes. The values of these parameters represent the mean of 3 independent replicates.

\section{Investigations}

\section{Proximate analysis}

Moisture, protein, fat and ash contents were determined according to the method of AOAC (2000). For determination of moisture contents $(\mathrm{g} / 100 \mathrm{~g}), 3 \mathrm{~g}$ of sample were dried at $100{ }^{\circ} \mathrm{C}$ until constant weight was obtained. Protein content $(\mathrm{g} / 100 \mathrm{~g})$ was determined according to the Kjeldahl method of analysis. For conversion of nitrogen into crude protein, a factor 6.25 was used. Fat $(\mathrm{g} / 100 \mathrm{~g})$ was determined by 6-cycle extraction with petroleum ether in a Soxhlet apparatus and calculating the weight loss. Ash was determined by ignition at $500{ }^{\circ} \mathrm{C}$ for $5 \mathrm{~h}(\mathrm{~g} / 100 \mathrm{~g})$. 
Measurement of soluble proteins

\section{Collagen solubility}

Collagen solubility was calculated according to the method described by Naewbanij et al. (1983) by heating $5 \mathrm{~g}$ from these samples to boiling temperature and holding them for $30 \mathrm{~min}$. The cooked meat was then cut into small pieces and homogenized with $50 \mathrm{ml}$ distilled water at $4 \pm 1{ }^{\circ} \mathrm{C}$ in a blender for $2 \mathrm{~min}$. The extract was then centrifuged (MLW T5, GRD) at $4500 \mathrm{rpm}$ for 30 min. Aliquots of cooked out juice and centrifugate were hydrolyzed for $18 \mathrm{~h}$. and soluble hydroxyproline was calculated.

\section{Sarcoplasmic proteins, total and myofibrillar proteins solubility}

Sarcoplasmic protein solubility was determined according to the method described by (Joo et al., 1999) through homogenizing one gram from each imported frozen Brazilian beef and Indian buffalo meat chuck samples in $10 \mathrm{ml}$ of ice-cold $25 \mathrm{mmol} / 1$ potassium phosphate buffer ( $\mathrm{pH}$ 7.2) using a stomacher (Lab blender 400) at the lowest setting. Homogenate was left to stand in a shaking water bath (GFL-1083, Germany) at $4 \pm 1^{\circ} \mathrm{C}$ overnight. The mixture was then centrifuged at $4500 \mathrm{rpm}$ for 20 minutes and the protein concentration of the supernatant was determined using Kjeldahl method (Tyszkiewicz and Klossowska, 1997).

Total soluble proteins were determined by homogenizing one gram from each chuck meat samples in $20 \mathrm{ml}$ ice-cold $1.1 \mathrm{~mol} / \mathrm{l}$ potassium iodide in a $100 \mathrm{~mol} / \mathrm{L}$ phosphate buffer $(\mathrm{pH}$ 7.2). The procedures for homogenization, shaking, centrifugation, and protein determination were the same as described for sarcoplasmic protein. Myofibrillar proteins were obtained by calculating the difference between total and sarcoplasmic protein.

\section{pH, total volatile base nitrogen $(T V B-N)$ and thiobarbituric acid (TBA) values}

For measurement of $\mathrm{pH}$ value, five grams of each chuck meat sample was homogenized with $20 \mathrm{ml}$ distilled water for 10-15 s (Kandeepan, et al., 2009). The $\mathrm{pH}$ was measured using a $\mathrm{pH}$ meter (Lovibond Senso Direct) with a probe type electrode (Senso Direct Type 330) which was calibrated every two samples using two buffers 7.0 and 4.0. The Total Volatile Base Nitrogen (TVB-N, $\mathrm{mg} / 100 \mathrm{~g}$ sample) was measured according to the method of Kearsley $\boldsymbol{e t}$ al. (1983) using a macro-Kjeldahl distillation method. Moreover, the thiobarbituric acid (TBA) value was measured by the method outlined by Du and Ahn (2002) and expressed as milligrams of malondialdehyde per kilogram of sample.

Color evaluation and measurement of shear force

Croma meter (Konica Minolta, model CR 410, Japan) has been used to measure the color of the examined chuck meat samples. The apparatus was calibrated using a white plate and light trap supplied by the manufacturer. The $\mathrm{L}^{*}$ (lightness), $\mathrm{a}^{*}$ (redness), and $\mathrm{b}^{*}$ (yellowness) values were obtained using CIE standard illuminant $\mathrm{D}_{65}$ light source. From each sample surface, three measurements were taken at each time. The average score of triplicate experiments was recorded, and expressed as CIE lightness ( $\left.\mathrm{L}^{*}\right)$, redness $\left(\mathrm{a}^{*}\right)$, and yellowness (b*) (Shin et al., 2008).

From each cooked meat block, four samples $(1 \mathrm{x} 1 \mathrm{x} 1 \mathrm{~cm})$ were cut parallel to the longitudinal orientation of muscle fibers, and the shear force was estimated by Instron Universal Testing Machine (Model 2519-105, USA). The shear force machine was adjusted at crosshead speed of $200 \mathrm{~mm} / \mathrm{min}$. An average shear force value was calculated and recorded for each sample (Shackelford et al., 2004).

\section{Fatty acid profile}

The total lipids from each of the examined chuck meat samples were extracted (in duplicate) with hexane at 1:50 (wt/vol) ratio in each extraction operation (Romero et al., 1998). The fatty acids content of each sample were extracted according to Folch et al. (1957). Lipid extracts of each sample were saponified for $30 \mathrm{~min}$. at $60^{\circ} \mathrm{C}$ with $40 \mathrm{ml} / \mathrm{g} 0.5 \mathrm{~N} \mathrm{NaOH}$ in methanol and then methylated with boron trifluoride-methanol complex to achieve complete conversion to methyl esters (IUPAC, 1987). The resultant fatty acid methyl esters were separated and analyzed by means of an automated gas liquid chromatograph equipped with a $1.8 \mathrm{~m} \times 3.2 \mathrm{~mm}$ stainless steel column packed in GP $10 \% \mathrm{sp} 2330$ on 100/200 Chromosorb WAW. The samples were chromatographed in a temperature gradient of $110-210^{\circ} \mathrm{C}$. The flow rate of the carrier gas (nitrogen) was $22 \mathrm{ml} / \mathrm{min}$. To each sample, a known amount of an internal standard (methyl laurate) was added. A standard of known composition was analyzed to verify the identity of the fatty acids in the samples. Fatty acid peaks determined by gas chromatography were then used to calculate amounts of fatty acids (g/100g FAME) according to calculations described by Slover and Lanza (1979).

\section{Sensory evaluation and cooking loss}

Meat chunks samples were wrapped with aluminum foil and cooked using hot air oven (Heraeus, D-63450 Hanau, Germany) at $180^{\circ} \mathrm{C}$. After chunks were exited in the cooking device, a needle thermocouple probe was inserted into the geometric center of the chunks and post-cooking temperature rise was monitored with previously calibrated hand-held thermometer (Hanna HI 985091-1, USA), to achieve a final core temperature of $70{ }^{\circ} \mathrm{C}$. Cooking loss percentage for each samples were calculated from the difference of weight before and after cooking. Prior to analysis, panelists from Department of Food Hygiene and Control Faculty of Veterinary Medicine, Cairo University were trained in the definition and intensities of different sensory attributes of imported frozen Brazilian beef and Indian buffalo meat. Cooked samples were coded with random numbers and evaluated by 5 well trained panelists. The panelists were asked to score each sample for appearance, flavor, tenderness, juiciness and overall acceptability using 8-points numerical scores with 8 - being highly desirable and 1 being highly undesirable (AMSA, 1995).

\section{Statistical analysis}

Statistical analysis for data was carried out using SPSS statistics 17.0 for windows. Data of proximate chemical composition, sensory evaluation, deterioration criteria, soluble proteins, shear force and colour values $\left(\mathrm{L}^{*}, \mathrm{a}^{*}\right.$ and $\left.b^{*}\right)$ of imported frozen Brazilian beef and imported frozen Indian buffalo were analyzed using Paired-samples $T$ test to compare results between the two different types of meat. Significances were determined using least square difference test (LSD) procedure. Differences were considered significant at the $P$ $<0.05$ level.

\section{RESULTS AND DISCUSSION}

\section{Proximate chemical analysis}

The results of proximate chemical composition revealed significantly $(P<0.05)$ higher moisture contents and significantly $(P<0.05)$ lower protein and fat contents in imported frozen Brazilian beef chuck meat when compared with the frozen Indian buffalo chuck meat samples. However, the ash content of imported frozen Brazilian meat chuck samples were not significantly $(P>0.05)$ different from that of imported frozen Indian meat chuck samples (Table 1). The results of moisture contents was not in agreement with Lapitan et al. (2008) and Aziz et al. (2012) who reported non-significant difference of moisture content between cattle and buffalo meat. Lower moisture contents for Indian frozen buffalo meat was observed by Brackebusche et al. (1991) and Alkhanky (2015). The obtained data for protein contents were in good agreement with Lapitan $\boldsymbol{e t}$ al. (2008), Aziz et al. (2012) and Kandeepan et al. (2013) who reported higher protein contents of buffalo meat in comparison with beef meat. However, lower protein contents for imported buffalo meat was recorded by Brackebusche $\boldsymbol{e t}$ al. (1991) and Alkhanky (2015). The data of fat contents were not in agreement with Aziz et al. (2012) who reported lower fat contents for buffalo meat in comparison with beef meat and Brackebusche et al. (1991) and Alkhanky (2015) who observed non-significant change in fat contents between buffalo and beef meat. Moreover, the data for ash contents were in agreement with Spanghero et al. (2004) who observed non-significant difference in ash contents between buffalo and beef. However, lower ash contents in buffalo meat was observes by Aziz et al. (2012).

\section{Soluble proteins}

The collagen solubility of imported frozen Brazilian beef meat chuck samples were significantly $(P<0.05)$ higher than that of Indian buffalo meat chuck samples (Table 2). These results were in good agreement with Naveena $\boldsymbol{e t}$ al. (2004) and Moon (2006). Lower collagen solubility values of beef were recorded by Koohmaraie et al. (1991) and Sullivan and Calkins (2010). However, higher collagen solubility for Indian male buffalo was observed by Kandeepan $\boldsymbol{e t}$ al. (2009). The total soluble proteins, sarcoplasmic soluble proteins and myofibrillar soluble proteins of Indian buffalo meat chuck samples revealed non-significan $(P>0.05)$ higher when compared with those of imported frozen Brazilian beef meat chuck samples (Table 2). Naveena et al. (2004) reported that the tota soluble protein, sarcoplasmic soluble protein and myofibrillar soluble protein of Indian buffalo meat were $8.12,1.91$ and $6.21 \mathrm{~g} / 100 \mathrm{~g}$, respectively which, were higher than the values obtained in this study. The soluble fraction of collagen present in meat is responsible for the extent of tenderness of the product and meat with higher salt soluble protein can retain more water to improve the cohesiveness and binding strength of the product during processing (Swan and Boles, 2006). Therefore, it can be expected that meat products processed from imported frozen Brazilian beef meat chuck will be tenderer and the meat products 
processed from imported frozen Indian buffalo meat will show improved cohesiveness and binding strength of processed products.

\section{Deterioration criteria}

The obtained data of deterioration criteria showed non-significant $(P>0.05)$ difference in $\mathrm{pH}, \mathrm{TVB}-\mathrm{N}$ and TBA values of imported frozen Brazilian beef and Indian buffalo meat chuck samples (Table 3$)$. A significantly $(P<0.05)$ higher $\mathrm{pH}$ values for imported frozen Brazilian beef were reported by Mohamed (2017) when compared with Indian buffalo meat samples and the author attributed these results to many inherent and exogenous factors including genetics, age, sex, diet, pre/post-slaughter handling and microbiota (Mach et al., 2008). A nonsignificant $(P>0.05)$ differences in TVB-N values of imported frozen Brazilian beef and Indian buffalo meat samples were recorded by Ebrahim $\boldsymbol{e t}$ al. (2011) and Mohamed (2017). A non-significant $(P>0.05)$ differences in TBARS values of imported frozen Brazilian beef and Indian buffalo meat samples were observed by Mohamed (2017) and Ghazalah (2013). However, higher TBA values for buffalo meat in comparison with beef were obtained by Ficco et al. (2010).

\section{Color and shear force values}

Imported frozen Brazilian beef meat chuck samples revealed significantly $(P<$ $0.05)$ higher $L^{*}$ values, significantly $(P<0.05)$ lower a* values and nonsignificantly $(P>0.05)$ different $b^{*}$ values when compared with imported frozen Indian buffalo meat chuck samples (Table 4). These observations were not in agreement with Ficco et al. (2010) who recorded higher L* values, lower a* values and lower $b^{*}$ values for buffalo meat when compared with those of beef meat. The higher $a^{*}$ values for imported frozen Indian buffalo meat samples may be attributed to it's higher sarcoplasmic soluble protein contents which, contribute to the colour of meat.

Imported frozen Brazilian beef meat chuck samples revealed significantly $(P<$ $0.05)$ lower shear force values in comparison with those of imported frozen Indian buffalo meat chuck samples (Table 4). These results were in agreement with Moon (2006) and Failla et al. (2007) who recorded non-significant difference in shear values of beef and buffalo Longissimus thoracis. However, they were not in agreement with those of Neath et al. (2007) who observed significantly lower shear force values for buffalo meat when compared with beef. A shear force value of $4 \mathrm{Kgf}$ for Indian buffalo meat was recorded by Naveena $e$ al. (2004) which, was lower than that obtained in this study. The higher shear force values for Indian buffalo meat may be explained by the lower collagen solubility. It has been also stated that the connective tissue in the buffalo meat had a higher contribution to toughness of that meat (Robertson et al., 1986).

\section{Fatty acid profile}

The results of Fatty acid profile revealed non-significant $(P>0.05)$ differences between imported frozen Brazilian beef and Indian buffalo meat chuck samples for all fatty acids except $\mathrm{C} 14: 0$ which was significantly $(P<0.05)$ higher in imported frozen Brazilian beef chuck samples. Moreover, there were no significant $(P>0.05)$ difference in total saturated, total unsaturated and trans fatty acids between imported frozen Brazilian beef and Indian buffalo meat chuck samples (Table 5). Previously, Mendoza et al. (2015) recorded significant $(P<$ 0.05) higher values for C17:0, C18:0, C20:0, C22:0, C24:0, C17:1 trans, C18:1 trans (elaidic), $\mathrm{C} 20: 1$ cis, $\mathrm{C} 20: 2$ cis $\omega 6, \mathrm{C} 20: 3$ cis $\omega 6, \mathrm{C} 20: 4 \omega 6$ and $\mathrm{C} 20: 5$ cis $\omega 3$ in Buffalo's intramuscular lipids of longissimus thoracis muscle when compared with those of Brahman beef. However, Brahman revealed significant $(P<0.05)$ higher values for $\mathrm{C} 14: 0, \mathrm{C} 15: 0, \mathrm{C} 16: 1$ trans, $\mathrm{C} 20: 3$ cis $\omega 3$ and $\mathrm{C} 22: 4 \omega 6$. It has been reported that the main saturated fatty acids present in beef intramuscular fat are palmitic (C16:0) and stearic acid (C18:0) (Frank et al., 2016; Hwang and Joo, 2017). Moreover, beef intramuscular fat showed a higher overall concentration of mono unsaturated fatty acids, especially oleic acid (C18:1 n-9) as well as polyunsaturated fatty acids (Joo et al., 2017). Meanwhile, Palmitic, stearic, oleic and linoleic acids were the most predominant fatty acids in the phospholipids of buffalo meat (Kesava and Kowale, 1991).

\section{Sensory evaluation}

The appearance, tenderness and juiciness scores of imported frozen Brazilian beef were significantly $(P<0.05)$ higher than those of Indian buffalo meat However, the falvor and overall acceptability scores of imported frozen Brazilian beef were not significantly $(P>0.05)$ higher than those of imported frozen Indian buffalo meat chuck samples (Table 6). It has been reported by Ghazalah (2013) that the odour and texture scores of imported frozen Brazilian and Indian meat were not significantly $(P>0.05)$ different. Meanwhile, Saleh et al. (2016) observed that the tenderness scores of Brazilian beef meat were significantly $(P<$ $0.05)$ higher than those of Indian buffalo meat. Spanghero et al. (2004) reported that the overall acceptability of raw buffalo and bovine meat were not significantly different, however, tenderness of beef was perceived to be significantly better than buffalo.

The lower scores for appearance in imported buffalo meat may be attributed to the darker color of this meat. This was in agreement with Kandeepan $\boldsymbol{e t}$ al. (2013) who observed that the major features of buffalo meat were its dark red colour, good marbling, low connective tissue and the desirable texture. The darker color which has been observed in imported frozen Indian buffalo chuck meat may be attributed to the higher soluble sarcoplasmic protein content in this meat. The lower scores for tenderness and juiciness of buffalo meat may be attributed to the significantly $(P>0.05)$ higher cooking loss percentagewhen it was compared with that of Brazilian beef meat (Table 6). This was in good agreement with Uriyapongson (2007) who observed that meat from buffalo was more tougher and less juicy than beef.

Table 1 Proximate chemical composition of Brazilian and Indian chuck meat samples

\begin{tabular}{lllll}
$\begin{array}{l}\text { Proximate chemical } \\
\text { composition }\end{array}$ & Moisture $(\mathrm{g} / 100 \mathrm{~g})$ & Protein $(\mathrm{g} / 100 \mathrm{~g})$ & Fat $(\mathrm{g} / 100 \mathrm{~g})$ & Ash $(\mathrm{g} / 100 \mathrm{~g})$ \\
\hline & & & & \\
Brazilian beef meat & $70.54^{\mathrm{a}} \pm 0.35$ & $22.04^{\mathrm{a}} \pm 0.38$ & $5.85^{\mathrm{a}} \pm 0.12$ & $1.45^{\mathrm{a}} \pm 0.08$ \\
Indian buffalo meat & $66.46^{\mathrm{b}} \pm 0.34$ & $24.39^{\mathrm{b}} \pm 0.34$ & $7.33^{\mathrm{b}} \pm 0.24$ & $1.61^{\mathrm{a}} \pm 0.09$
\end{tabular}

${ }^{a-b}$ Means with different superscripts within the same column are significantly $(P<0.05)$ different.

* Values represent the mean of 3 independent replicates \pm SE

Table 2 Soluble proteins of Brazilian and Indian chuck meat samples

\begin{tabular}{lllll}
\hline Soluble proteins & $\begin{array}{l}\text { Collagen solubility } \\
(\mathrm{g} / 100 \mathrm{~g})\end{array}$ & $\begin{array}{l}\text { Total soluble protein } \\
(\mathrm{g} / 100 \mathrm{~g})\end{array}$ & $\begin{array}{l}\text { Sarcoplasmic soluble } \\
\text { protein }(\mathrm{g} / 100 \mathrm{~g})\end{array}$ & $\begin{array}{l}\text { Myofibrillar } \\
\text { soluble protein } \\
(\mathrm{g} / 100 \mathrm{~g})\end{array}$ \\
\hline Brazilian beef meat & $0.07^{\mathrm{a}} \pm 0.01$ & $7.34^{\mathrm{a}} \pm 0.41$ & $4.57^{\mathrm{a}} \pm 0.26$ & $2.77^{\mathrm{a}} \pm 0.25$ \\
Indian buffalo meat & $0.04^{\mathrm{b}} \pm 0.00$ & $7.75^{\mathrm{a}} \pm 0.33$ & $4.61^{\mathrm{a}} \pm 0.26$ & $3.15^{\mathrm{a}} \pm 0.36$ \\
\hline
\end{tabular}

Means with different superscripts within the same column are significantly $(P<0.05)$ different

* Values represent the mean of 3 independent replicates \pm SE 
Table 3 Deterioration criteria of Brazilian and Indian chuck meat samples

\begin{tabular}{|c|c|c|c|}
\hline Deterioration criteria & pH & TVB-N (mg/100g) & TBA (mg/kg) \\
\hline Brazilian beef meat & $5.88^{\mathrm{a}} \pm 0.07$ & $9.54^{\mathrm{a}} \pm 0.55$ & $0.43^{\mathrm{a}} \pm 0.06$ \\
\hline Indian buffalo meat & $5.87^{\mathrm{a}} \pm 0.07$ & $9.55^{\mathrm{a}} \pm 0.44$ & $0.47^{\mathrm{a}} \pm 0.07$ \\
\hline
\end{tabular}

* Values represent the mean of 3 independent replicates \pm SE

Table 4 Color and shear force values of Brazilian and Indian chuck meat samples

\begin{tabular}{ccccc}
\hline \multicolumn{1}{l}{ Table 4 Color and shear force values of Brazilian and Indian chuck meat samples } & \multicolumn{1}{l}{ Color } & Shear force (Kgf) \\
\hline & $\mathbf{L}^{*}$ & $\mathbf{a}^{*}$ & & \\
\cline { 2 - 4 } & & & $11.19^{\mathrm{a}} \pm 0.41$ & $3.80^{\mathrm{a}} \pm 0.43$ \\
Brazilian beef meat & $40.08^{\mathrm{a}} \pm 0.36$ & $20.23^{\mathrm{a}} \pm 0.37$ & & $5.13^{\mathrm{b}} \pm 0.54$ \\
\hline Indian buffalo meat & $37.09^{\mathrm{b}} \pm 0.84$ & $22.05^{\mathrm{b}} \pm 1.24$ & $10.66^{\mathrm{a}} \pm 0.54$ & \\
\hline
\end{tabular}

${ }^{\mathrm{a}-\mathrm{b}}$ Means with different superscripts within the same column are significantly $(P<0.05)$ different

* Values represent the mean of 3 independent replicates $\pm \mathrm{SE}$

Table 5 Fatty acid profile (g/100g FAME) of Brazilian and Indian meat chucks samples

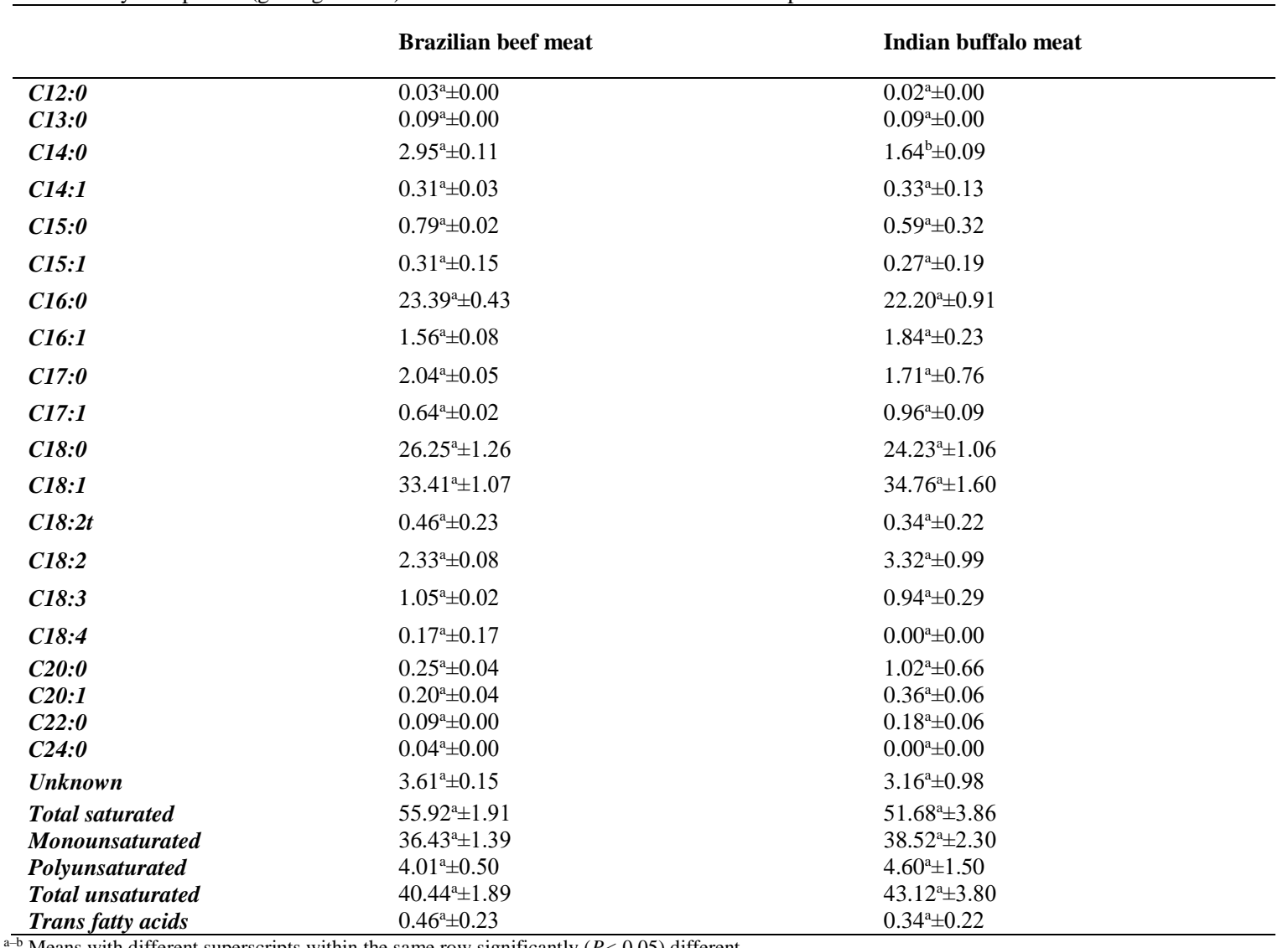

${ }^{a-b}$ Means with different superscripts within the same row significantly $(P<0.05)$ different.

* Values represent the mean of 3 independent replicates \pm SE.

Table 6 Sensory quality and cooking loss percentage of cooked Brazilian and Indian chuck meat samples

\begin{tabular}{cccccc}
\hline & Appearance & Flavor & Tenderness & Juiciness & $\begin{array}{c}\text { Overall } \\
\text { acceptability }\end{array}$ \\
\hline $\begin{array}{c}\text { Brazilian } \\
\text { beef meat } \\
\text { Indian } \\
\text { buffalo } \\
\text { meat }\end{array}$ & $6.50^{\mathrm{a}} \pm 0.16$ & $5.94^{\mathrm{a}} \pm 0.33$ & $5.61^{\mathrm{a}} \pm 0.42$ & $5.50^{\mathrm{a}} \pm 0.21$ & $5.50^{\mathrm{a}} \pm 0.41$ \\
\end{tabular}

${ }^{\mathrm{a}-\mathrm{b}}$ Means with different superscripts within the same column are Significantly $(P<0.05)$ different.

* Values represent the mean of 3 independent replicates $\pm \mathrm{SE}$ 


\section{CONCLUSION}

It could be concluded from the current study that Indian buffalo meat has higher protein and fat contents with lower moisture contents when compared with Brazilian beef meat. Moreover, the fatty acid composition of Indian buffalo fat was not significantly different than that of Brazilian beef. These attributes can make Indian buffalo meat a good choice for meat processing after Brazilian beef meat. These results will help meat processors to find an alternative source for raw meat materials for production of high quality meat products.

Acknowledgments: This study was financially supported from Faculty of Veterinary Medicine, Cairo University, Cairo, Egypt.

\section{REFERENCES}

ABDELAZIZ, A. E., HAMED, O. M., GHAFAR, M. W. 2017. Detection of Escherichia coli in Frozen Meat, Liver, Heart and Kidney Imported in to Egypt. Research Journal of Pharmaceutical, Biological and Chemical Sciences RJPBCS, 8(2), 1270-1278

ABIEC "Associação Brasileira das Indústrias Exportadoras de Carnes" 2014 Balanço da pecuária brasileira. Retrieved May 15, 2014, from http://apps.fas.usda.gov/psdonline/.

ALKHANKY, S. F. E. 2015. Physicochemical and sensory parameters as indices to evaluated the quality of imported frozen meat. M.V. Sc. Thesis, Faculty of Veterinary medicine, Suez Canal University.

AL-SABAGH, E. S., TAHA, N. M., SALEH, E. A., EL-FAR, A. H., SADEK, K. M. 2016. Effect of freezing and frozen storage on amino acid profile and fatty acid pattern in imported and local meat. Alexandrian Journal of Veterinary Science, 49(1), 113- 121. https://doi.org/10.5455/ajvs.209080

AMSA "American Meat Science Association" 1995. Research guidelines for cookery, sensory evaluation and instrumental tenderness measurements of fresh meat. Chicago, IL, USA: American Meat Science Association.

AOAC "Association of Official Analytical Chemists" 2000. Official Methods of Analysis. Association of Official Analytical Chemists. $17^{\text {th }}$ Ed., Washington, DC USA.

AROEIRA, C. N., FILHO, R. A. T., FONTES, P. R., GOMIDE L. A. M., RAMOS, A. L. S., LADEIRA, M. M., RAMOS, E. M. 2016. Freezing, thawing and aging effects on beef tenderness from Bos indicus and Bos taurus cattle. Meat Science, 116, 118-125. https://doi.org/10.1016/j.meatsci.2016.02.006 AZIZ, A., SHAH, A. H., KHASKHELI, I. E. M., SALMAN, M., TALPUR, A R. 2012. Comparative studies on nutritional quality of cattle and buffalo meat. International Journal of Science and Research (IJSR), 3(7), 524-531.

BADAWI, M. B. A. 2008. Further study on imported frozen meat. Ph. D Thesis in Food Hygiene, Faculty of veterinary Medicine, Alexandria University.

BRACKEBUSCHE, S. A., MCKEITH, F. K., CARR, T. R., MCLAREN, D. G. 1991. Relationship between longissimus composition and the composition of other major muscles of the beef carcass. Journal Animal Science, 69, 631-640. https://doi.org/10.2527/1991.692631x

DU, M., AHN, D. U. 2002. Effect of antioxidants on the quality of irradiated sausages prepared with turkey thigh meat. Poultry Science, 81, 1251-1256. https://doi.org/10.1093/ps/81.8.1251

EBRAHIM, H. M., SALEM, A. M., ELD, A. M., MOUHAMED, N. A. 2011 Chemical indices of imported frozen meat. Benha Veterinary Medicine, 1(2), 1-6. FAILlA, S., VINCENTI, F., SALTARELli, E., CONTÒ, M., BALLICO, S., FICCO A. 2007. Aging time effect on quality meat from buffaloes fed on two different diets. Italian Journal of Animal Science, 6(2), 1195-1198. https://doi.org/10.4081/ijas.2007.s2.1195

FAO "Food and Agriculture Organization" 2004. FAO Production Year Book. FAO, Rome, Italy.

FICCO, A., CONTO, M., BALliCO, S., FICCO, G., FAILlA, S., BORGHESE, A. 2010. Effect of packaging and aging time on shelf-life of buffalo meat compared to yak and beef meat. $9^{\text {th }}$ World Buffalo Congress, Buenos Aires, Argentina, 506-507.

FOLCH, J., LEES, M., SLOANE-STANLEY, G. H. 1957. A simple method of the isolation and purification of total lipids from animal tissues. Journal of Biochemical Chemistry, 226 (1), 497-509.

FRANK, D., JOO, S. T., WARNER, R. 2016. Consumer acceptability of intramuscular fat. Korean Journal of Food Science of Animal Resources, 36, 699-708. https://doi.org/10.5851/kosfa.2016.36.6.699

GOVS "General Organization for Veterinary Service " 2017. Report of the central Administration of Veterinary Quarantine and Inspection.

GHAZALAH, S. 2013. Quality assurance of frozen meat. Ph.D. Thesis in meat hygiene. Faculty of Veterinary Medicine, Damanhour University.

HWANG, Y. H., JOO, S. T. 2017. Fatty acid profiles, meat quality, and sensory palatability of grain-fed and grass-fed beef from Hanwoo, American, and Australian crossbred cattle. Korean Journal of Food Science of Animal Resources, 37(2), 153-161. https://doi.org/10.5851/kosfa.2017.37.2.153

IUPAC "International Union of Pure and Applied Chemistry" 1987. Standard Methods for the Analysis of Oils, Fats and Derivatives. pp.163-169. C. Paquot and A. Hautfenne (Eds). Blackwell Scientific Publications, Oxford.
JOO, S. T., KAUfFMAN, R. G., KIM, B. C., PARK, G. B. 1999. The relationship of sarcoplasmic and myofibrillar protein solubility to color and water holding capacity in porcine Longissimus muscle. Meat Science, 52, 291-297. https://doi.org/10.1016/s0309-1740(99)00005-4

JOO, S. T., HWANG, Y. H., FRANK, D. 2017. Characteristics of Hanwoo cattle and health implications of consuming highly marbled Hanwoo beef. Meat Science, 132, 45-51. https://doi.org/10.1016/j.meatsci.2017.04.262

KANDEEPAN, G., ANJANEYULU, A. S. R., KONDAIAH, N., MENDIRATTA, S. K. LAKSHMANAN, V. 2009. Effect of age and gender on the processing characteristics of buffalo meat. Meat Science, 83, 10-14 https://doi.org/10.1016/j.meatsci.2009.03.003

KANDEEPAN, G., MENDIRATTA, S. K., SHUKLA, V., VISHNURAJ, M. R. 2013. Review of processing characteristics of buffalo meat-. Journal of Meat Science and Technology, 1(1), 1-11.

KEARSLEY, M. W., EL-KHATIB, L., GUNU, C. O. K. A. 1983. Rapid determination of total volatile nitrogen in fish and meat. Association of Public Analysts, 21, 123-128.

KESAVA, R. V., KOWALE, B. N. 1991. Changes in phospholipids of buffalo meat during processing and storage. Meat Science, 30(2), 115-129. https://doi.org/10.1016/0309-1740(91)90002-8

KOOHMARAIE, M., WHIPPLE, G., KRETCHMAR, D. H., CROUSE, J. D., MERSMANN, H. J. 1991. Postmortem proteolysis in longissimus muscle from beef, lamb and pork carcasses. Journal of Animal Science, 69, 617-624. https://doi.org/10.2527/1991.692617x

LAPITAN, R. M., DEL BARRIO, A. N., KATSUBE, O., BAN-TOKUDA, T., ORDEN, E. A., ROBLES, A. Y., CRUZ, L. C., KANAI, Y., FUJIHARA, T. 2008. Comparison of carcass and meat characteristics of Brahman grade cattle (Bos indicus) and crossbred water buffalo (Bubalus bubalis) fed on high roughage diet. Journal of Animal Science, 79, 210-217. https://doi.org/10.1111/j.1740-0929.2008.00519.x

MACH, N., BACH, A., VELARDE, A., DEVANT, M. 2008. Association between animal, transportation, slaughterhouse practices, and meat $\mathrm{pH}$ in beef Meat Science, 78(3), 232-238. https://doi.org/10.1016/j.meatsci.2007.06.021 MENDOZA, M. G., DE MORENO, L. A., LEIDENZ, N. H., BRACHO, S. U., LEAL, K. V., ROMERO, S., GONZÁLEZ, A. R. 2015.Cholesterol and fatty acid composition of longissimus thoracis from water buffalo (Bubalus bubalis) and Brahman-influenced cattle raised under savannah conditions, Meat Science, 106, $44-49$.

https://doi.org/10.1016/j.meatsci.2015.03.024

MOHAMED, A. S. I. 2017. Quality Assessment of imported frozen meat, M V Sc thesis, Zagazig University, Faculty of Veterinary Medicine Department of Food Hygiene and Control, Egypt.

MOON, S. S. 2006. The effect of quality grade and muscle on collagen contents and tenderness of intramuscular connective tissue and myofibrillar protein for hanwoo beef. Asian Australasian Journal of Animal Sciences, 19(7), 1059-1064. https://doi.org/10.5713/ajas.2006.1059

NAEWBANIJ, J. O., DOROTHY, L. H., STONE, M. B. 1983. Roasting vs cooking in a model system: Tenderness of bull adductor muscle, conventionally chilled or electrically stimulated -Hot boned. Journal of Food Science, 48, 337 342. https://doi.org/10.1111/j.1365-2621.1983.tb10738.x

NAVEENA, B. M., MENDIRATTA, S. K., ANJANEYULU, A. S. R. 2004 Tenderization of buffalo meat using plant proteases from Cucumis trigonus roxb (Kachri) and Zingiber officinale roscoe (Ginger rhizome). Meat Science, 68(3), 363-369. https://doi.org/10.1016/j.meatsci.2004.04.004

NEATH, K. E., DEL BARRIO, A. N., LAPITAN, R. M., HERRERA, J. R. V., CRUZ, L. C., FUJIHARA, T., MUROYA, S., CHIKUNI, K., HIRABAYASHI, M., KANAI, Y. 2007. Difference in tenderness and pH decline between water buffalo meat and beef during post-mortem aging. Meat Science, 75, 499-505 https://doi.org/10.1016/j.meatsci.2006.08.016

ROBERTSON, J., RATCTIFF, D., BOUTON, P. E., HARRIS, P. V. SHORTHOSE, W. R. 1986. A comparison of some properties of meat from young buffalo (Bubalus bubalis) and cattle. Journal of Food Science, 56(1), 47 50. https://doi.org/10.1111/j.1365-2621.1986.tb10832.x

ROMERO, A., CUESTA, C., SANCHEZ-MUNIZ, F. J. 1998. Effect of oil replenishment during deep fat frying of frozen foods in sunflower oil and higholeic acid sunflower oil. American Oil Chemist's Society, 75 (2), 161-167. https://doi.org/10.1007/s11746-998-0028-5

SALEH, E.A., EL-MOHSEN, R. G. A., IBRAHIM, M. S. 2016. Molecular identification of Staphylococcus aureus in imported frozen and locally slaughtered meat. Alexeria Journal of Veterinary Science, 51(1), 162-169. https://doi.org/10.5455/ajvs.244653

SHACKELFORD, S. D., WHEELER, T. L., KOOHMARAIE, M. 2004 Evaluation of sampling, cookery, and shear force protocols for objective evaluation of lamb Longissimus tenderness. Animal Science, 82, 802-807. https://doi.org/10.1093/ansci/82.3.802

SHIN, H., CHOI, Y., KIM, H., RYU, Y., LEE, S., KIM, B. 2008. Tenderization and fragmentation of myofibrillar proteins in bovine Longissimus dorsi muscle using proteolytic extract from Sarcodon aspratus. Food Science and Technology, 41, 1389-1395. https://doi.org/10.1016/j.1wt.2007.08.019 
SLOVER, H. T., LANZA, E. 1979. Quantitative analysis of food fatty acids by capillary gas chromatography. American Oil Chemistry Society, 56 (12), 933934. https://doi.org/10.1007/bf02674138

SPANGHERO, M., L. GRACCO, R. V., PIASENTIER, E. 2004. In vivo performance, slaughtering traits and meat quality of bovine (Italian Simmental) and buffalo (Italian Mediterranean) bulls. Livestock Production Science, 91, 129 141. https://doi.org/10.1016/i.livprodsci.2004.07.013

SULliVAN, G. A., CALKINS, C. R. 2010. Application of exogenous enzymes to beef muscle of high and low-connective tissue. Meat Science, 85(4), 730-734 https://doi.org/10.1016/j.meatsci.2010.03.033

SWAN, J. E., BOLES, J. A. 2006. Functionality of cow beef in coarse and fine ground model systems. Meat Science, 72(1), 25-33. https://doi.org/10.1016/j.meatsci.2005.05.024

TYSZKIEWICZ, I., KLOSSOWSKA, B. M. 1997. Mechanical tenderisation of pork meat: protein and water release due to tissue damage. Science of Food and Agriculture, 73, 179-185. https://doi.org/10.1002/(sici)1097-0010(199702)73

Uriyapongson, J. 2007. Comparison and improvement of chemical and physical characteristics of low- fat ground beef and buffalo meat patties at frozen storage Italian Journal of Animal Science, 6(2), 1171-1174. https://doi.org/10.4081/ijas.2007.s2.1171

USDA "United State Department of Agriculture" 2014. USDA foreign agricultural service. Retrieved May, 2014, from http://apps.fas.usda.gov/psdonline/

VERNAM, A. H., SUTHERLAND, J. P. 1995. Meat and meat products $1^{\text {st }}$ Ed. Chapman and Hall, London. 